

\section{Organizational Culture Types and Their Effects on Organizational Performance in Turkish Hospitals}

\author{
Dr. A. Zafer Acar \\ Pinar Acar
}

\section{Introduction}

The effects of globalization, developments in information and communication technologies, and increase in the variety of products/services according to the customer expectations are the most important dynamics in today's economy. Every firm uses some strategies whether explicit or not while competing to gain competitive advantage in this harsh environment, and in the competitive struggle of each product/service market, some firms are successful with achieving competitive advantage while others fail (Walker, 2009: 1). Competitive advantage is reflected in superior economic performance compared to rivals. Thus, one of the most fundamental questions in the field of strategic management field is why some firms in the same industry have systematically performed better than others (Crook et al., 2006; Teece, Pisano, and Shuen, 1997).

In business world, it is considered that usually a well planned strategy brings the company success. This idea led many organizations to imitate the strategies of successful businesses. However, time, technology, market and competition rules are changing. So, a firm's strategy must shift to meet them (Walker, 2009: 15), and this changing must be continuously (Fleisher, and Bensoussan, 2003: 2). Therefore, it has already emerged that, to imitate competitors' strategies is not the only way to compete and to gain competitive advantage. According to Porter's (1996) perspective, the strategy is based on unique activities. To be successful against rivals, a business has to select different set of activities and should provide a unique value. The sustainability of this competitive advantage depends on obtaining the economic value which was created by competitors' capabilities (Fleisher and Bensoussan, 2003: 2).

In today's fast and continuous environmental changes and intense competition, the contribution of the employees is key determinant for the success of the organization. For businesses, their employees' work performance with great effort and combining their own personal goals with organizational purposes are crucial to create most of the valuable, rare, inimitable and nonsubstitutable capabilities. Beyond the contribution of the employees those rapid changes need to respond automatically. And, according to developments in external environment these strategic situations need adoption of organizational culture with a continuous perception, evaluation, implementation and revision within the balance of internal dynamics rather than a topdown planning. So, this perspective gives general patterns of behaviour to organizational culture to deal with and solve the problems encountered of the employees in the organization within the socialization process. At this point, orders and directives are no need to be too detailed.

On this account, the response of organizations to situations which are emerged due to pressures of external environment and internal dynamics will vary according to their organizational culture. In this context, it is expected that, as a result of the methods of response to the external environment as proactive or reactive, the obtained performance vary according to different organizational culture. Especially, the needs on qualitative aspects of manpower for labor-intensive and one-to-one customer relationships, organizational culture in service industry has become a strategic value which placed in business. Healthcare, as a service industry, experienced one-to-one contact with customers and has large impact of organizational culture on customers' performance perceptions.

Healthcare industry, especially hospitals, consist an important part of the service sector. As hospitals play a crucial role in diagnosis of illness, they effect on human life and their well-being directly. Thus, they are different from the other service industries. Besides the important role of hospitals on public health, healthcare industry also plays an important role in the economy. The industry determines the GDP (gross domestic production), exports status, capital investment of any country.

Turkey's annual healthcare spending in 2009 was USD 38 billion, representing 6.2 percent of total GDP, and annual healthcare spending per one person in 2012 was $600 \$$. The healthcare system in Turkey is being developed under the 2003-2013 Health Transformation Program. Moreover healthcare industry is getting more competitive due to those liberal policies of governments in Turkey. Both public and private sector hospital numbers have been growing rapidly in recent years. As of 2011, the number of hospitals and total number of beds are 1,439 and 194,504, respectively (Deloitte, 2011). Despite the importance in national economy, 
healthcare industry is typical in service industries. And, organizational culture is one of the important determinants of business performance in service industries. Thus this study is performed on hospitals which represent healthcare industry.

As the other industries, healthcare industry tends to be more competitive. Especially in Turkish context competitiveness is scaling up with implemented exchange programs and liberalization policies on national basis. This conditions force the health services. So, while serving the health services, hospitals, as a business, have an effort to achieve basic economic objective.

Although the literature abound of evidences that the organizational culture, as an intangible force, is one of most important factors that affect performance, managers try to change the current organizational culture which based on public economy era to others which appropriate with liberal economy. So, because of those structural changes on the industry and on a hospital itself from public base to liberal economy a "cultural transformation" (Scott et al., 2003) is seen.

It's easily said that every hospital as an organization has a corporate culture. And, as a living organization, people make a hospital work and its cultures ties people together, giving meaning and purpose to their day to day activities and lives (Arnold, Capella, and Sumrall, 1987). The need to diagnose and manage corporate culture is growing in importance, partly because of an increasing need to merge and mold different corporate cultures as structural changes have occurred such as consolidation, capitalism, and merger of hospitals (Cameron and Quinn, 1999).

According to these reasons, current study aims to reveal the organizational culture types of private and public healthcare institutions in Turkey and identify the dominant organizational culture within public and private hospitals while make a comparison between them. Than examine the effects of organizational culture on organizational performance. In this context, organizational culture concept is explained according to the literature. Then hypotheses were developed about the effects of current levels of health institutions within the framework of these concepts on business performance.

In order to test developed hypotheses in the healthcare industry, as a universe of our research, employees of private and public hospitals in large cities of Turkey are selected. For our research, a total of 99 hospitals are accepted to be the subject of this research and a total of 480 questionnaires were collected from participants. Hypotheses were tested with principal component and regression analysis by using SPSS 15 program. We expected that the results of this study will bring different perspectives on performance dynamics of organizations in increasingly liberalized health industry.

In this framework this study consists of four parts. In the following part the concept of organizational culture and its effects on organizational performance will be explained according to the literature. Then the developed hypotheses about the effects of current levels of healthcare institutions within the framework of these concepts on business performance will be given. Sampling, data collection, scale validity and reliability, and analysis of the research question can be seen in the third part. Finally, the paper will be ended with discussing and synthesizing the empirical findings and implications to researcher and professionals will be in this last part. We expected that the results of this study will bring different perspective on performance dynamics of organizations in competitive and increasingly liberalized healthcare industry.

\section{Literature Review and Theoretical Framework}

The concept of culture has principally stemmed from the study of ethnic and national differences in the varied disciplines of social sciences. Organizational culture is claimed that one of the main factors required for understanding organizations. Thus, the concept of organizational culture has examined many times by management and organizational scholars over the last decades. According to this interest, there have been many academic studies about organizational culture from various perspectives. Organizational culture denotes a wide range of social phenomena which help to define an organization's character and norms, including an organization's customary dress, language, behaviour, beliefs, values, assumptions, symbols of status and authority, myths, ceremonies and rituals, and modes of deference and subversion (Scott et al., 2003). Although there is a considerable overall agreement as to the general definition of organizational culture, most of the academics prefer to use various definitions that differing according to approach to the concept. So, it will be better to express here the most known definition of organizational culture, besides it's appropriate definition with current study. Schein (1997) defined organizational culture as a pattern of shared basic assumptions that the group learned as it solved its problems that has worked well enough to be considered valid and is passed on to new members as the correct way to perceive, think, and feel in relation to those problems.

According to the organizational behaviour literature the concept of organizational culture has four key characteristics. First, organizational culture is a shared phenomenon (Schein, 1997: 8; Wilson, 2001; 
Baumgartner, 2009). Second, organizational culture has visible and less visible levels (Schein, 1997: 17; Wilson, 2001; Baumgartner, 2009). Third, each new member of the organization learns the culture (Wilson, 2001; Baumgartner, 2009) especially with socialization. Finally, culture tends to change slowly over time (Wilson, 2001; Baumgartner, 2009) the synergistic structure formed by employees of the organization who shared same values, beliefs and moving towards common goals.

According to Cameron and Quinn (1999), organizational culture is defined as an enduring set of the core values, assumptions, interpretations and approaches that characterize organizations and their members. In general, it has been claimed by many researchers that, success-oriented organizational culture increases organizational effectiveness (Deal and Kennedy, 1982; Furnham, 1997; Kotter and Heskett, 1992; Peters and Waterman, 1982; Schein 1997; Denison, 1990). In this context the effect of organizational culture on organizational performance is studied within different constructs in several studies (e.g. Gordon and DiTomaso, 1992; Ogbonna and Harris, 2000; Poll, 2000). Even it is determined that, organizational culture created competitive advantage (e.g. Scholz, 1987; Krefting and Frost; 1985). In some studies in our country (e.g. Eren, Alpkan, and Ergün, 2003), it has been identified that culture has an effect on organizational performance through internal integration and external focus.

Cameron and Quinn (1999), in their study, investigated the contribution of developed organizational culture on organizational effectiveness of organizational success. In that study, it is claimed that each of the organizational culture types may contribute to organizational success depending on the needs of external environment and strategic orientation of organization. Accordingly in current study, organizational performance has taken as dependent variable and organizational culture types were considered as independent variables. According to Cameron and Quinn (1999) typology, culture in an organization can be seen between two dimensions: a focus on internal maintenance (smoothing and integration) versus external relationships (competition and differentiation), and a focus on organic processes (flexibility and dynamism) versus mechanistic processes (stability and control). In Competitive Values Framework (CVF) model, the four dominant organizational culture types - hierarchy, market, clan and adhocracy emerge from the intersection quadrants of those axes of the framework.

Clan (cooperative) culture is shaped between the dimensions of organization focus and flexibility/dynamism. The clan culture possesses high affiliation and concern with teamwork and participation
(Quinn and Spreitzer, 1991). Organizational commitment is a culture type which has seen in organizations, acting as family and has social features as trust, solidarity and unity. Successful Japanese firms with effective team structure are typical examples of this culture (Berrio, 2003, Cameron and Quinn, 1999; Erdem, 2007).

Hierarchy (control) culture is located between internal organization focus and stability/control dimensions. The hierarchical culture reflects values and norms associated with bureaucracy (Quinn and Spreitzer, 1991). This is an organizational culture type which the leadership is effective because it is in mechanical and bureaucratic organizations that give importance to order and rules. This culture can be seen in global companies like McDonald's and Ford Motor Co. leads to worker alienation, purposelessness and decrease in the sense of autonomous (Berrio, 2003, Cameron and Quinn, 1999; Erdem, 2007).

Although there is an external focus/orientation, Market (competitive) culture occurs at the time of stability and control. This is a rational culture which emphasizes efficiency and achievement (Quinn and Spreitzer, 1991). Employees in these culture types are success-oriented. They give importance to personal interests rather than organizational goals and emphasis on the concepts of planning, performance and efficiency. Global businesses which have effective relationship between suppliers, customers and external stakeholders are examples of this organizational culture (Berrio, 2003, Cameron and Quinn, 1999; Erdem, 2007).

Adhocracy (creative) is a developmental organizational culture which is based on risk taking, innovation and change (Quinn and Spreitzer, 1991). It refers to the culture of an organization in entrepreneurial, flexible, innovative and creative areas with its externaloriented and dynamic structure. Employees can take the initiative, supported with new discoveries and freedoms so they feel satisfied, happy and successful in this environment (Berrio, 2003, Cameron and Quinn, 1999; Erdem, 2007). Organizations, doing business over the internet which is defined as 'new economy', using advanced technology are examples of this culture.

Based on these foresight and findings from the literature, depending on traditional roots of the public and private sector, it is predicted that there are different types of organizational culture of the companies in these two sectors. In this context the first hypothesis is expressed as follows:

H1: There is a significance difference between organizational culture types of public and private sector.

Arnold and colleagues claimed that corporate culture has a powerful influence throughout a hospital on such matters as who gets promoted, what decisions are made, and even how employees act (Arnold, Capella, 
and Sumrall, 1987). In the literature, it is expressed in different ways that organizational culture is one of the hidden powers of business performance. However, it is revealed that the difference between the types of organizational culture at the same time lead to different performance outcomes. In this context the following hypotheses are expressed as follows:

H2: Adhocracy culture has direct and positive effects on business performance.

H3: Clan culture has direct and positive effects on business performance.

H4: Hierarchy culture has direct and positive effects on business performance.

H5: Market culture has direct and positive effects on business performance.

As a result of liberalization of healthcare industry, public hospitals had to compete against private hospitals. Also variety of financial audits put into practice forced managers of public hospitals to demonstrate performance-oriented management. However, it is expected that there are performance differences among public institutions and private sector organizations which the survival is depending on the level of income and profitability. In this context the following hypothesis is expressed as follows:

H6: There are significant differences of the effects of organizational culture types on performance outcomes depending on the different types of hospital ownership.

\section{Methodology}

It is difficult to evaluate corporate culture because of beliefs, values and assumptions that shared in an organization are not always explicit (Schein, 1997). So, qualitative approaches are advantageous in detailing the environmental factors influencing this socialization process (Klingle et al., 1995).

Thus, to reveal the corporate culture in the hospitals and to test the above hypotheses qualitative approach is used and a questionnaire survey was performed. Data gathered from chosen sample were evaluated by the help of SPSS V.15 statistical package program. After reliability of our scales is confirmed factor, correlation and regression analyses are conducted to investigate the relationships among variables.

\section{Measurement Instrument}

Multi-item scales that used in this survey are adapted from previous studies to structure measurement scales. The validity and reliability of those scales are confirmed in related studies in the international arena. Thus theoretical background of the current scales which explain below is very strong.

Scott and colleagues (2003) studied 13 measurement instruments that used to assess organizational culture. Organizational culture instruments have been vary according to its typological approach, power of theoretical and conceptual provenance, scope of dimensions and exploring the deeper manifestation of culture (Scott et al., 2003). In current study a constructivist approach is accepted, so a typological tool is preferred. However choosing the constructivist approach, there are many classifications of organizational culture and it's vary according to the researches' choices of theoretical models based on their studies. The equilibrium between pressures of organization's external environment and the dynamics of internal environment are the basis of classification in our study. On this context, Scott and colleagues (2003) offer the Competing Values Framework (CVF), which is specially designed to represent the balance of different cultures within the same organization, to the researchers who take more constructivist approach. Thus we decided to use the revised model of the Organizational Culture Assessment Instrument (OCAI) based upon the CVF (Cameron and Quinn, 1999; Cameron et al., 2007; Helfrich et al., 2007; Goodman, Zammuto, and Gifford, 2001; Öztop, 2008; Quinn and Kimberly, 1984) to determine the cultural dimensions. On the other hand, most of the measurement instruments examine the employee perceptions and opinions about their working environment (the so-called "climate" of an organization, but the CVF tries to examine the values, beliefs and unspoken assumptions that guide attitudes and behaviours (Scott et al., 2003). The CVF clarifies the complex nature of organizational culture and provides taxonomy of cultural values that reflect preferred structural characteristics and desired modes of operation. The structure of CVF was designed to differentiated organizational culture according to two dimensions: internal/external focus, and stability/flexibility. Using these two dimensions, four quadrants occur as representing Clan (team), Adhocracy (entrepreneurial), Hierarchical, and Market (rational) cultures.

We took into consideration the output of business performance within three factors that evaluate the perceived, customer and financial performance of the businesses. Those performance scales used in this questionnaire are taken from most commonly used scales in the literature (Venkatraman and Ramanujan, 1986; Baker and Sinkula, 1999; Antoncic and Hisrich, 2001; Zahra, Neubaum, and El-Hagrassey, 2002; Chang et al., 2003; Rozenzweig, Roth, and Dean Jr., 2003) and also taken form models previously applied on Turkish 
companies (Acar, 2010; Acar and Zehir, 2009; Altındağ, Zehir, and Acar, 2011; Zehir, Altındağ, and Acar, 2010).

These scales were translated by the authors, then a bilingual academics back-translated the instrument. Through interviews with various academics and managers, it is questioned whether there is disorder or ambiguity of the expression. Any discrepancies were rewritten to be cleared and then back-translated once again (Brislin, 1970). In the final stage, with using 5point Likert-type scales ranging from "strongly disagree" (1) to "strongly agree" (5), the final shape was given to scale and applied to corporate executives.

\section{Sampling}

The aim of this study is to reveal the organizational culture types in the hospitals and examine the relationships between organizational culture and business performance. In order to test the developed hypotheses current study was carried out in healthcare industry in Turkey. In this research, questionnaire survey technique has been used as a method of data collection. First, private and public hospitals are chosen as sample of our research. But the exact population of the hospitals in Turkey is 1439. According to the Ministry of Health (2011) database 490 of them are private and 949 of them are public hospitals in Turkey. With the purpose of getting appropriate data to test the research model the research universe is narrowed in respect of geographical regions. In this stage we selected random sampling, and applied to 300 private and public hospitals in İstanbul, İzmir, Bursa, Antalya, Samsun, Malatya and Kocaeli provinces due to availability of the data easily. This quantity holds more than $20 \%$ of Turkey's hospital population. Also, this regions occupies nearly $1 / 3$ portion of Turkey's population. 37 private and 62 public hospitals accepted to be subject of this research. It means $7,5 \%$ of private and $6,5 \%$ of public hospitals, totally $6,9 \%$ of Turkey's hospital population. We sent the questionnaire forms to the executives with a cover letter. After gathering the data we eliminated some questionnaire because of faulty inputs. Then a database was formed with the 512 returned questionnaires of those 99 hospitals. We compared early and late respondents to evaluate the non-response bias. No significant differences were found between early and late respondents on all variables. After the elimination of some questionnaire forms because of excessive data hiding, 480 clear questionnaires were taken to the analysis stage. Also, a comparison was made between the eliminated surveys and those chosen for analysis in terms of means, firm size and firm age, and it was seen that there is no difference between them in a statistical sense.
After gathering the data, the basic features of the data were described with statistics to provide simple summaries about respondents. According to the descriptive analysis; $64,37 \%$ of the respondents are female and 35,63 \% are male, 24,37\% were graduated vocational school and below, while $75,63 \%$ of them have university and higher degrees. $32,5 \%$ of the participants are under 30 years of age and $31,46 \%$ is in the $30-39$ age range, which are the vast majority of our respondents. In addition, $17,71 \%$ of the participants are doctors, $14,58 \%$ of them are managers, $18,54 \%$ are administrative staff and $49,17 \%$ of them are nurses. This data shows that the sample represents young, middle-level educated and dynamic audience and the close proportion of the staff in hospitals. Additionally the portion of nurses to the doctors is appropriate to the suggestion of Scott and colleagues (2003). Thus, it is considered that this sampling will positively affect the accuracy of our research, due to their basic knowledge about the concepts of the research. Some descriptive results are given in the Table 1.

Table 1: Descriptive statistics of the sample

\begin{tabular}{|c|c|c|c|c|c|c|}
\hline \multicolumn{3}{|c|}{ Gender } & \multicolumn{4}{|c|}{ Age } \\
\hline & Freq. & $\%$ & & Freq. & $\%$ & Valid \% \\
\hline Female & 309 & 64,37 & $20-29$ & 156 & 32,50 & 37,96 \\
\hline Male & 171 & 35,63 & $30-39$ & 151 & 31,46 & 36,74 \\
\hline Total & 480 & & $40-49$ & 65 & 13,54 & 15,82 \\
\hline \multicolumn{3}{|c|}{ Status } & $50-+$ & 43 & 8,96 & 10,46 \\
\hline & Freq. & $\%$ & Total & 411 & 84,46 & 100,00 \\
\hline Doctor & 85 & 17,71 & Missing & 65 & 13,54 & \\
\hline Manager & 70 & 14,58 & Total & 480 & 100,00 & \\
\hline Admin. staff & 89 & 18,54 & & & & \\
\hline Nurse & 236 & 49,17 & \multicolumn{4}{|c|}{ Tenure } \\
\hline Total & 480 & & & Freq. & $\%$ & Valid \% \\
\hline \multicolumn{3}{|c|}{ Education } & $1-5$ & 118 & 24,58 & 26,20 \\
\hline & Freq. & $\%$ & 6- 10 & 107 & 22,29 & 23,80 \\
\hline Primary sch. & 5 & 1,04 & $11-15$ & 87 & 18,12 & 19,30 \\
\hline High sch. & 64 & 13,33 & $15-20$ & 84 & 17,51 & 18,80 \\
\hline Vocational sch. & 48 & 10,00 & $20-+$ & 53 & 11,04 & 11,90 \\
\hline Under graduate & 271 & 56,46 & Total & 449 & 93,54 & 100,00 \\
\hline Master \& Ph.D. & 92 & 19,17 & Missing & 31 & 6,46 & \\
\hline Total & 480 & & Total & 480 & 100,00 & \\
\hline
\end{tabular}

\section{Scale Validity and Reliability}

In current empirical study, all items and components are tested by comprehensive reliability analyses. At first, it's analyzed the alpha reliability test; overall scale reliability coefficient has been determined a satisfactory level such that $\alpha=, 955$; this value is quite over the recommended 0,70 threshold (Nunnally, 1978; Nunnally and Bernstein, 1994). Reliability coefficients of the main scales in our research model are identified as; Organizational Culture scale 0,932 and Business Performance scale 0,955 respectively. These findings informed us that the results are reliable. 
In the variable analysis, there is no item founded which has low value of corrected inter-item correlation, squared multiple correlation and/or impair the scale reliability. In the exploratory factor analysis procedure, Kaiser-Meyer-Olkin (KMO) and Bartlett's test results were examined. The results showed that, data are suitable for the principle component analysis (PCA), reliable and validity of the construct is provided. Then, the principle factor analysis was applied to identify the components of the factors having eigenvalues greater than one. During the factor analysis, varimax rotation was applied with taking into account the generalization of the results. In the data reduction procedure, those variables having a factor load of 0.500 and above were taken into the account. This application maximizes the sum of the variances necessary for the factors matrix (Hair et al., 1998: 110). According to the PCA findings all items separated to their estimated factorial components without any cross loading. Factor loading values are found out between 0,540 and 0,859 . The results of principal component analysis of the Organizational Culture scale can be seen in Table 2.

Table 2: The results of principal component analysis of the culture scale

\begin{tabular}{|c|c|c|c|c|}
\hline & Market & Adhocracy & Clan & Hierarchy \\
\hline C01 & &, 781 & & \\
\hline C02 & &, 825 & & \\
\hline C03 & &, 776 & & \\
\hline C04 & &, 737 & & \\
\hline C05 & &, 722 & & \\
\hline C06 & & &, 620 & \\
\hline C07 & & &, 721 & \\
\hline C08 & & &, 707 & \\
\hline C09 & & &, 716 & \\
\hline C10 & & &, 744 & \\
\hline C11 & & & &, 821 \\
\hline C12 & & & &, 859 \\
\hline C13 & & & &, 601 \\
\hline C14 & & & &, 544 \\
\hline C15 & & & &, 540 \\
\hline C16 &, 802 & & & \\
\hline C17 &, 803 & & & \\
\hline C18 &, 809 & & & \\
\hline C19 &, 798 & & & \\
\hline C20 &, 808 & & & \\
\hline KMO: ,917; X $: 7348,55 ; \mathrm{P}<0,001 ;$ Total variance explained: \\
\hline
\end{tabular}

Before examining the relationships among the factors in our research model, as one of the most important criteria in which we would evaluate the validity of the results, the data was examined to determine if it had normal distribution. For this purpose, the scale structure that was obtained with factor analysis was evaluated with the Kolmogorov-Smirnov test, and it was seen that $t$ values of all of the variables were at the sufficient level for our sample ( $t \min =3,702 ; p<0,001)$. These findings prove that the distribution of the data is statistically normal. Furthermore, considering the fact that the validity and the reliability of the items we used in the current research scale have been tested in previous studies, the confirmatory factor analysis procedure was not applied.

During the principal component analysis of performance scale, the factor structure of 12 variables scale is divided into three components instead of two components as expected. However, while evaluation of the factor structure, it has seen that all components are significant between them and named as service, financial and perceived performance. The results of principal component analysis of the performance scale are shown in Table 3.

Table 3: The results of principal component analysis of the performance scale

\begin{tabular}{|c|c|c|c|}
\hline & $\begin{array}{l}\text { Service } \\
\text { Perf. }\end{array}$ & $\begin{array}{l}\text { Financial } \\
\text { Perf. }\end{array}$ & $\begin{array}{l}\text { Perceived } \\
\text { Perf. }\end{array}$ \\
\hline $\begin{array}{l}\text { 1. Increase in the number } \\
\text { of employees }\end{array}$ & & & 808, \\
\hline $\begin{array}{l}\text { 2. Increase in the level of } \\
\text { satisfaction of employees }\end{array}$ & & & 804 \\
\hline $\begin{array}{l}\text { 3. Increase in the level of } \\
\text { loyalty of employees }\end{array}$ & & & ,727 \\
\hline $\begin{array}{l}\text { 4. Increase in the number } \\
\text { of patient }\end{array}$ & 617 & & \\
\hline $\begin{array}{l}\text { 5. Decrease in the patient } \\
\text { complaints }\end{array}$ & ,753 & & \\
\hline $\begin{array}{l}\text { 6. Patients' satisfaction } \\
\text { level }\end{array}$ & ,793 & & \\
\hline $\begin{array}{l}\text { 7. Increase in the level of } \\
\text { loyalty of available } \\
\text { patients }\end{array}$ & ,777 & & \\
\hline $\begin{array}{l}\text { 8. Image and effects on } \\
\text { society }\end{array}$ & 682, & & \\
\hline $\begin{array}{l}\text { 9. Increase in service } \\
\text { quality }\end{array}$ & 679, & & \\
\hline $\begin{array}{l}\text { 10. Financial success of } \\
\text { new services offer to the } \\
\text { market }\end{array}$ & & ,796 & \\
\hline $\begin{array}{l}\text { 11. Position in the } \\
\text { competitive environment } \\
\text { and market }\end{array}$ & & 832 & \\
\hline $\begin{array}{l}\text { 12. The overall level of } \\
\text { success in terms of finance }\end{array}$ & & ,770 & \\
\hline \multicolumn{4}{|c|}{$\begin{array}{c}\text { KMO: ,914; } \mathrm{X}^{2} \text { : 3599,44; } \mathrm{p}<0,001 \text {; Total variance explained: } \\
72,287\end{array}$} \\
\hline
\end{tabular}

\section{Test of the Research Question}

This research aims to reveal the mostly seen organizational culture types in hospitals of Turkey, and to state what kind of effect of those different 
organizational culture types and ownership have on the performance of healthcare institutions. For this purpose a questionnaire survey was performed and a database was composed. Based on the psychometric properties of the constructs of the database it was determined that the measures were sufficient and could be employed in hypotheses. Then to reach research aim, primarily descriptive statistical analyzes were conducted. According to the descriptive analyzes which is done by regulation of the data obtained by survey based on business, within the framework of our sample, the most common organizational culture type in hospitals in our country is founded as hierarchy culture both in private and public sector. And it is followed by market culture. The most common organizational culture types in hospitals and the distribution according to the ownership differences are shown in Table 4.

Table 4: Common organizational culture types seen in hospitals

\begin{tabular}{|l|c|c|c|c|c|c|}
\hline & \multicolumn{2}{|c|}{ General (480) } & \multicolumn{2}{c|}{ Private (254) } & \multicolumn{2}{c|}{ Public (226) } \\
\hline & Mean & $\begin{array}{c}\text { Std. } \\
\text { Dev. }\end{array}$ & Mean & $\begin{array}{c}\text { Std. } \\
\text { Dev. }\end{array}$ & Mean & $\begin{array}{c}\text { Std. } \\
\text { Dev. }\end{array}$ \\
\hline Hierarchy & 3,627 & 0,947 & 3,880 & 0,812 & 3,342 & 1,008 \\
\hline Market & 3,434 & 1,096 & 3,730 & 1,041 & 3,101 & 1,062 \\
\hline Clan & 3,306 & 1,200 & 3,683 & 1,069 & 2,882 & 1,199 \\
\hline Adhocracy & 3,284 & 1,224 & 3,613 & 1,051 & 2,916 & 1,300 \\
\hline
\end{tabular}

H1 hypothesis is composed whether organizational culture types significantly differ between public and private sector hospitals? To analyze this hypothesis, independent t-test is conducted (see Appendix 1). The results showed that there is a significant difference between the variances of organizational culture in public and private hospitals except market culture. Thus, hypothesis H1 is supported. Before testing the direct relationships correlation analysis is conducted to test the relationship between variables in the research model. Results of correlation analysis revealed that all constructs which differed from each other as components are mutually correlated with each other positively and significantly $(\mathrm{p}<0,01)$. The results of the correlation analysis and the Cronbach's alpha coefficients of the dimensions can be seen in Table 5 .
Table 5: Mutual relationship between variables of the research model

\begin{tabular}{|l|c|c|c|c|c|c|c|}
\hline Components & $\mathbf{1}$ & $\mathbf{2}$ & $\mathbf{3}$ & $\mathbf{4}$ & $\mathbf{5}$ & $\mathbf{6}$ & $\mathbf{7}$ \\
\hline Adhocracy & $1(, 827)$ & & & & & & \\
\hline Clan &, $766^{* *}$ & $1(, 826)$ & & & & & \\
\hline Hierarchy &, $508^{* *}$ &, $500^{* *}$ & $1(, 820)$ & & & & \\
\hline Market &, $340^{* *}$ &, $331^{* *}$ &, $523^{* *}$ & $1(, 835)$ & & & \\
\hline Perceived perf. &, $353^{* *}$ &, $364^{* *}$ &, $436^{* *}$ &, $452^{* *}$ & $1(, 826)$ & & \\
\hline Service perf. &, $311^{* *}$ &, $319^{* *}$ &, $436^{* *}$ &, $457^{* *}$ &, $640^{* *}$ & $1(, 829)$ & \\
\hline Financial_perf &, $368^{* *}$ &, $348^{* *}$ &, $440^{* *}$ &, $444^{* *}$ &, $578^{* *}$ &, $692^{* *}$ & $1(, 826)$ \\
\hline ** All mutual relations $\mathrm{p}<0,01$ (two-sided) level is significant \\
\hline
\end{tabular}

Subsequently to examine the mutual relations of the factors in the research model, a predicted linear relationship in hypotheses was tested by regression analysis. Regression analysis is used to describe the relationship between dependent variable and independent variable which assumed to have an effect on it. As a result of the analysis, to find the percentage of total change in the dependent variable which is explained by independent variable, $\mathrm{R}^{2}$ is used which defines the rate of variation on data set (Hair et al., 1998). The results of the regression analysis related with $\mathrm{H} 2$ - $\mathrm{H} 5$ hypotheses are shown in Table 6. Explanatory power of the regression model statistically means that organizational culture has a significant effect on the emergence of the business performance. According to the regression analyses H2 and $\mathrm{H} 3$ hypotheses are partially supported while $\mathrm{H} 4$ and H5 hypotheses are supported.

Table 6: The effects of organizational culture on business performance (all scale)

\begin{tabular}{|l|c|c|c|c|c|c|}
\hline & \multicolumn{2}{|c|}{$\begin{array}{c}\text { Perceived } \\
\text { Performance }\end{array}$} & \multicolumn{2}{c|}{$\begin{array}{c}\text { Service } \\
\text { Performance }\end{array}$} & \multicolumn{2}{c|}{$\begin{array}{c}\text { Financial } \\
\text { Performance }\end{array}$} \\
\hline & Beta & $\mathrm{t}$ & Beta & $\mathrm{t}$ & Beta & $\mathrm{t}$ \\
\hline $\begin{array}{l}\text { H2 } \\
\text { Adhocracy }\end{array}$ &, 061 & 0,984 &, 033 & 0,520 &, $132 *$ & 2,100 \\
\hline $\begin{array}{l}\text { H3 } \\
\text { Clan }\end{array}$ &, $124 *$ & 1,996 &, 082 & 1,314 &, 051 & 0,803 \\
\hline $\begin{array}{l}\text { H4 } \\
\text { Hierarchy }\end{array}$ &, $189 * * *$ & 3,643 &, $216^{* * *}$ & 4,142 &, $199 * * *$ & 3,789 \\
\hline $\begin{array}{l}\text { H5 } \\
\text { Market }\end{array}$ &, $288 * * *$ & 6,176 &, $303^{* * *}$ & 6,445 &, $275^{* * *}$ & 5,839 \\
\hline & $\begin{array}{r}\mathrm{R}^{2}: 27,9 ; \mathrm{F}: \\
45,278 ; \mathrm{p}<0,001\end{array}$ & $\begin{array}{c}\mathrm{R}^{2}: 26,9 ; \mathrm{F}: \\
42,976 ; \mathrm{p}<0,001\end{array}$ & $\begin{array}{c}\mathrm{R}^{2}: 27,6 ; \mathrm{F}: \\
43,644 ; \mathrm{p}<0,001\end{array}$ \\
\hline \multicolumn{7}{|c|}{$* * * \mathrm{p}<0,001 ; * * \mathrm{p}<0,01 ; * \mathrm{p}^{*}<0,05$} \\
\hline
\end{tabular}

In order to solve the hypothesis H6, at first, the differences of the performance variables in the data set according to changes in ownership is examined by an independent t-test (see Appendix 2). According to the findings, it is revealed that, even the performance values of private hospitals on those three business performance sub-factors are higher than public hospitals the 
differences between those two groups are not statistically significant. Thus, the effects of organizational culture differences on business performance in regard of both public and private hospitals are not calculated. However, data set is divided into two as public and private and the effects of organizational culture on business performance are re-examined. According to the analyses, the effects of Organizational Culture on the business performance of public hospitals are shown in Table 7.

Table 7: The effects of organizational culture on business performance (public)

\begin{tabular}{|c|c|c|c|c|c|c|}
\hline & \multicolumn{2}{|c|}{$\begin{array}{c}\text { Perceived } \\
\text { Performance }\end{array}$} & \multicolumn{2}{|c|}{$\begin{array}{c}\text { Service } \\
\text { Performance } \\
\end{array}$} & \multicolumn{2}{|c|}{$\begin{array}{c}\text { Financial } \\
\text { Performance } \\
\end{array}$} \\
\hline & Beta & $\mathrm{t}$ & Beta & $\mathrm{t}$ & Beta & $\mathrm{t}$ \\
\hline Adhocracy & ,139 & 1,442 & ,135 & 1,345 & ,166 & 1,667 \\
\hline Clan & ,115 & 1,243 & ,004 & 0,046 & 036 & 0,378 \\
\hline Hierarchy &, $177^{*}$ & 2,450 &, $247 * * *$ & 3,283 &, $285^{* * *}$ & 3,794 \\
\hline \multirow[t]{3}{*}{ Market } &, $227 * * *$ & 3,436 &, $172 * *$ & 2,511 & 096 & 1,408 \\
\hline & \multicolumn{2}{|c|}{$\begin{array}{c}\mathrm{R}^{2}: 25,8 ; \mathrm{F}: \\
18,917 ; \mathrm{p}<0,001\end{array}$} & \multicolumn{2}{|c|}{$\begin{array}{c}R^{2}: 19,9 ; F: \\
13,560 ; p<0,001\end{array}$} & \multicolumn{2}{|c|}{$\begin{array}{c}R^{2}: 22,5 ; F: \\
15,471 ; p<0,001\end{array}$} \\
\hline & \multicolumn{6}{|c|}{$* * * \mathrm{p}<0,001 ; * * \mathrm{p}<0,01 ; * \mathrm{p}<0,05$} \\
\hline
\end{tabular}

The effects of Organizational Culture on the business performance of private hospitals are shown in Table 8.

Table 8: The effects of organizational culture on business performance (private)

\begin{tabular}{|l|c|c|c|c|c|c|}
\hline & \multicolumn{2}{|c|}{$\begin{array}{c}\text { Perceived } \\
\text { Performance }\end{array}$} & \multicolumn{2}{c|}{$\begin{array}{c}\text { Service } \\
\text { Performance }\end{array}$} & \multicolumn{2}{c|}{$\begin{array}{c}\text { Financial } \\
\text { Performance }\end{array}$} \\
\hline & Beta & $\mathrm{t}$ & Beta & $\mathrm{t}$ & Beta & $\mathrm{t}$ \\
\hline Adhocracy &, 019 & 0,248 &,- 052 & $-0,684$ &, 101 & 1,312 \\
\hline Clan &, 126 & 1,593 &, 128 & 1,628 &, 052 & 0,646 \\
\hline Hierarchy &, $190^{* *}$ & 2,651 &, 132 & 1,852 &, 049 & 0,683 \\
\hline Market &, $329 * * *$ & 5,079 &, $415^{* * *}$ & 6,426 &, $441^{* * *}$ & 6,744 \\
\hline & $\begin{array}{c}\mathrm{R}^{2}: 28,0 ; \mathrm{F}: \\
23,722 ; \mathrm{p}<0,001\end{array}$ & $\begin{array}{c}\mathrm{R}^{2}: 28,5 ; \mathrm{F}: \\
24,308 ; \mathrm{p}<0,001\end{array}$ & $\begin{array}{c}\mathrm{R}^{2}: 27,7 ; \mathrm{F}: \\
22,998 ; \mathrm{p}<0,001\end{array}$ \\
\hline & \multicolumn{6}{|c|}{$* * * \mathrm{p}<0,001 ; * * \mathrm{p}<0,01 ; * \mathrm{p}<0,05$} \\
\hline
\end{tabular}

According to the results of the analyses that shown in Table 7 and 8 the differences between public and private hospitals in regard of the effect of Organizational Culture on their Business Performance are as follows:

- Although, the effects of hierarchy culture on service and financial performance are seen in public hospitals, the same effect couldn't be ascertained in private hospitals.
- $\quad$ Although, the effects of market culture on financial performance are seen in private hospitals, the same effect couldn't be ascertained in public hospitals.

\section{Discussion and Conclusion}

The purpose of the current study was to identify the dominant culture and empirically explain the relationships among organizational culture types and business performance in hospitals as a healthcare service firms. However as yield in the literature, culture is ambiguous, often slippery, and difficult to measure, qualitative approaches are advantageous to study on such kind of this socialization process. Thus, it is decided to perform a questionnaire survey. During the literature review process, it is seen that organizational culture instruments have been vary according to its aim, scope, and theoretical approach. In this qualitative study, to reveal the organizational culture of hospitals revised model of the Organizational Culture Assessment Instrument (OCAI) based upon the CVF is used. And, a multi-item business performance scale which is adapted from previous studies is used.

Data collected from 512 employees of 99 hospitals of majors cities in Turkey. According to the descriptive statistics it is found out that the dominant organizational culture in the Turkish healthcare industry is Hierarchy and it is followed by Market and Clan cultures. However it is limited by the sample, this finding can be interpreted as corporate culture in Turkish healthcare industry bases on stability, order and control. Even every case in hospitals is different from the others this result is surprising because of these kinds of organizations which are effective in emphasizing stable, predictable, and mechanistic processes.

Corporate culture has a powerful influence throughout a hospital on many aspects. While evaluation of studies of organizational culture and organizational performance concepts, it is emerged that organizational culture is directly linked to the performance of an organization (e.g. Denison, 1990). Our study provides additional empirical evidence from healthcare services in Turkey to the research stream on organizational culture. Ogbonna and Harris (2000) offer that an internally oriented organizational culture may prove comparatively disadvantageous when compared to the advantages possible with externally oriented cultures. Nevermore, according to the findings of the current study, it's hard to reach superior performance in service and financial performance aspects with Clan culture. However, these results also partially supported the results of Ogbonna and Harris' (2000) study. But current study demonstrates 
that Turkish healthcare organizations are mostly in a hierarchical culture. In this sense, in the case of internally oriented cultures, little evidence is found to support claims of a link between cultural strength and performance. On the other hand, according to findings of current research it's found out that organizational culture which considers stability, order and control behaviours dominantly are comparatively in advantageous position with the organizations which are in flexibility, discretion and dynamism. This paradox should be the main problem to solve by professionals in healthcare industry in Turkish context.

In respect of to these findings, it can be said that, private hospitals in Turkey have not yet transformed a competitive and innovative structure keeping pace with dynamic market conditions and showed a controlled and organization focused approach in line with incoming past experience from public hospitals. On the basis of public and private hospitals, the significance difference between the effects of organizational culture on business performance couldn't be ascertained. This finding supports our prediction about the creation of cultural structure of private hospitals by public experienced personnel, however, it still needed to be tested.

Moreover, the obvious differences between public and private hospitals and the effect of market culture in public hospitals on financial performance were not observed within the framework of our sample. Conversely, the relation is seen as positive in private hospitals. Hence, it is statistically supported that competitive structure of the private sector calls forth positive financial results. Despite the effects of hierarchy culture on service and financial performance seen in public hospitals, the same effect couldn't be ascertained in private hospitals. So, in our opinion, this can be the most important finding in our research. This finding means that hierarchy culture still dominates in private hospitals and institutions have to slowly give up this structure. Thus, performance differences in public and private hospitals are not founded statistically significant therefore, our forecast is needed to be tested.

The findings and results of this study need to be reviewed critically in light of several limitations. It should be noted that the findings of this study were a result of a small sample size. Scott and colleagues (2003) offered that in a particular hospital the proportion of managers to doctors is $1: 4$ and of doctors to nurses is $1: 3$, then the sample from that hospital might comprise 3 managers, 12 doctors, and 36 nurses. According to the findings, we collected approximately five questionnaires from each hospital. Thus the use of the small number of participants in each hospital in the study, acts to decrease the generalizability of the findings.
Lastly, this is not important to identify just the corporate culture of hospitals. But, as Hood and colleagues (2003) expressed before it is also necessary to manage it in order to achieve sustainable change in care delivery and, hence; improved outcomes. So, further studies might perform to reveal the antecedents of the corporate culture in the hospitals. Moreover, it can be examined within a large database that whether ownership, location leadership style differences or stakeholder priorities have effect on corporate culture.

\section{References}

Acar, A. Z. 2010. "Lojistik Yeteneklerin, Strateji Performans Ilişkisi Üzerindeki Rolü: KOBİ'ler Üzerinde Bir Saha Araştırması" (The effect of logistics capabilities on the relationship between strategy and performance: An application on SMEs). Atatürk Üniversitesi İ̈BF Dergisi, 24(4): 1-21.

Acar, A. Z., and Zehir, C. 2009. "Krizden Çıkışta KOBİ'lerde Temel Işletme Yeteneklerinin Rolü ve Işletme Performansına Etkileri” (The effects of business capabilities on business performance of SMEs during out of crisis). 6ncı KOBİ'ler ve Verimlilik Kongresi, 323333, 17-18 Kasım 2009, Kültür Üniversitesi, İstanbul.

Altındağ, E., Zehir, C., and Acar, A. Z. 2011. "Strategic Orientations and Their Effects on Firm Performance in Turkish Family Owned Firms". Eurasian Business Review, 1: 16-34

Antoncic, B., and Hisrich, R. D. 2001. "Intrapreneurship: Construct Refinement and Cross-Cultural Validation". Journal of Business Venturing, 16: 495-527.

Arnold, D., Capella, L., and Sumrall, D. 1987. "Organization Culture and the Marketing Concept: Diagnostic Keys for Hospitals". Journal of Health Care Marketing, 7(1): 18-28.

Baker W. E., and Sinkula, J.M. 1999. "The Synergistic Effect of Market Orientation and Learning Orientation on Organizational Performance". Journal of the Academy of Marketing Science, 27(4): 411-427. 
Baumgartner, R. J. 2009. “Organizational Culture and Leadership: Preconditions for the Development of a Sustainable Corporation". Sustainable Development, 17: 102-113.

Berrio, A. A. 2003. "An Organizational Culture Assessment Using the Competing Values Framework: A Profile of Ohio State University Extension". Journal of Extension, 41(2), http://www.joe.org/joe/2003april/a3.php

Brislin, R. W. 1970. "Back-Translation for CrossCultural Research". Journal of Cross-Cultural Psychology, 1: 185-216.

Cameron, K. S., and Quinn, R. E. 1999. Diagnosing and Changing Organizational Culture: Based on the Competing Values Framework. Reading. MA: Addison-Wesley.

Cameron, K. S., Quinn, R. E., Degraff, J., and Thakor, A. 2007. Competing Values Leadership: Creating Value in Organizations. MA: Edward Elgar Publishing.

Chang, S.-C., Lin, N.-P., Yang, C.-L., and Sheu, C. 2003. "Quality Dimensions, Capabilities and Business Strategy: An Empirical Study in High-Tech Industry". Total Quality Management, 14(4): 407-421.

Crook, T. R., Bratton, V. K., Street, V. L., and Ketchen, D. J. 2006. "Has Strategic Management Shed the Normal Science Straightjacket?: Revisiting Bettis' (1991) Critiques". Journal of Managerial Issues, 18(3): 409-23.

Deal, T. E., and Kennedy, A. A. 1982. Corporate Cultures the Rites and Rituals of Corporate Life. New York: Addison-Wesley.

Deloitte 2011. Turkish Healthcare Industry Report. Republic of Turkish Prime Ministry, www.invest.gov.tr

Denison, D. R. 1990. Corparate Culture and Organizational Effectiveness. New York: John Wiley \& Sons.
Erdem, R. 2007. “Örgüt Kültürü Tipleri ile Örgütsel Bağlılık Arasındaki Ilişki: Elazı̆̆ İl Merkezindeki Hastaneler Üzerinde Bir Çalışma" (The relationships between types of organizational culture and organizational commitment: A study on hospitals at city center of Elazig). Eskişehir Osmangazi Üniversitesi IIIBF Dergisi, 2(2): 63-79.

Eren, E., Alpkan, L., and Ergün, E. 2003. "Kültürel Boyutlar Olarak Işletmelerde Içsel Bütünleşme ve Dişsal Odaklanma Düzeylerinin Performansa Etkileri" (The effects on the managerial performance of the levels of internal integration and external orientations cultural dimensions within the firms). Doğuş Üniversitesi Dergisi, 4(1): 55-70.

Fleisher, C. S., and Bensoussan, B. E. 2003. Strategic and Competitive Analysis. New Jersey: Prentice Hall.

Furnham, A. 1997. The Psychology of Behavioural Work. Brighton, New York: Psychology Press Ltd.

Gordon, G. G., and DiTomaso, N. 1992. "Predicting Corporate Performance from Organizational Culture". Joumal of Management Studies, 29(6): 783-98.

Goodman, E. A., Zammuto, R. F., and Gifford, B. D. 2001. "The Competing Values Framework: Understanding the Impact of Organizational Culture on the Quality of Work Life". Organization Development Journal, 19(3): 5868.

Hair, J. F, Anderson, R. E., Tatham, R. L., and Black, W. C. 1998. Multivariate Data Analysis (5th ed.). Upper Saddle River, NJ: Prentice-Hall.

Helfrich, C. D., Li, Y-F., Mohr, D. C., Meterko, M., and Sales, A. E. 2007. "Assessing an Organizational Culture Instrument based on the Competing Values Framework: Exploratory and Confirmatory Factor Analyses". Implementation Science, 2: 1-14, DOI: 10.1186/1748-5908-2-13.

Hood, J., Smith, H., and Waldman, J. 2003. "Corporate Culture: The Missing Piece of the Healthcare Puzzle". Hospital Topics: Research and Perspectives on Healthcare, 81(1): 5-14. 
Klingle, R. S., Burgoon, H. M., Afifi, W. A., and Callister, M. (1995). "Rethinking How to Measure Organizational Culture in the Hospital Setting: The Hospital Culture Scale". Evaluation and the Health Professions, 18: 166-186.

Kotter, J. P., and Heskett, J. L. 1992. Corporate Culture and Performance. New York: Free Press.

Krefting, L. A., and Frost, P. J. 1985. "Untangling Webs, Surfing Waves, and Wildcatting: A Multiple Metaphor Perspective on Managing Organisational Culture". In: Frost, P. J. et al (eds) Organizational Culture. London: Sage.

Nunnally J. 1978. Psychometric Theory. New York: McGraw-Hill.

Nunnally, J. C., and Bernstein, I. H. 1994. Psychometric Theory (3rd ed.). McGraw-Hill, New York.

Ogbonna, E. and Harris, L. C. 2000. "Leadership Style, Organizational Culture and Performance: Empirical Evidence from UK Companies". International Journal of Human Resource Management, 11(4): 766-788.

Öztop, İ. 2008. "The relationship between leadership styles and culture styles and the impact of this relationship on the qualitative performance (Liderlik tarzlari ve örgüt kültürü tipleri arasindaki ilişki ve bu ilişkinin nitel performans üzerine etkileri). Master's thesis, GYTE, Kocaeli.

Peters, T. J., and Waterman, R. H. 1982. In Search of Excellence: Lessons from America's Best-Run Companies. New York: Harper and Row.

Poll, S. 2000. "Organizational Culture and its Relationship between Job Tension in Measuring Outcomes among Business Executives". Journal of Management Development, 19(1): 32-49.

Porter, M. E. 1996. "What is Strategy?" Harvard Business Review, 74 (Nov.-Dec.): 61-78.
Quinn, R. E., and Kimberly, J. R. 1984. "Paradox, Planning, and Perseverance: Guidelines for Managerial Practice". In Kimberly, J.R. and Quinn, R.E. (Eds.), Managing Organizational Transitions, 295-313. Homewood, IL: Dow Jones-Irwin.

Quinn, R. E., and Spreitzer, G. M. 1991. "The Psychometrics of the Competing Values Culture Instrument and an Analysis of the Impact of Organizational Culture on Quality of Life". Research in Organizational Change and Development, 5: 115-142.

Rosenzweig, E. D., Roth, A. V., and Dean Jr., J. W. 2003. "The Influence of an Integration Strategy on Competitive Capabilities and Business Performance: An Exploratory Study of Consumer Products Manufacturers". Journal of Operations Management, 21: 437-456.

Schein, E. H. 1997. Organizational Culture and Leadership (2nd Ed.). San Francisco: JosseyBass.

Scholz, C. 1987. "Corporate Culture and Strategy - The Problem of Strategic Fit". Long Range Planning, 25 (Winter): 3-16.

Scott, T, Mannion, R., Davies, H., and Marshall, M. 2003. "The Quantitive Measurement of Organizational Culture in Health Care: A Review of the Available Instruments". Health Services Research, 38 (3): 923-945.

Teece, D. J., Pisano, G., and Shuen, A. 1997. "Dynamic Capabilities and Strategic Management". Strategic Management Journal, 18(7): 509-33.

Venkatraman, N. , and Ramanujan V. 1986. "Measurement of Business Performance in Strategy Research: A Comparison of Approaches". Academy of Management Review, 11(4): 801-814.

Walker, G. 2009. Modern Competitive Strategy (3rd ed.). Singapore: The McGraw-Hill.

Wilson, A. M. 2001. "Understanding Organizational Culture and Implications for Corporate Marketing". European Journal of Marketing, 35: 353-367. 
Zahra, S. A., Neubaum, D. O., and El-Hagrassey, G. M. 2002. "Competitive Analysis and New Venture Performance: Understanding the Impact of Strategic Uncertainty and Venture Origin". Entrepreneurship Theory and Practice, 27(1): 1-28.
Zehir, C., Altındağ, E., and Acar, A. Z. 2010. "Aile Şirketlerinde Stratejik Yönelim Düzeyleri ve Firma Performansı İlişkisi” (Strategic orientations in family owned business and its relationship with business performance). 18nci Ulusal Yönetim Organizasyon Kongresi, 538546, 20-22 Mayıs 2010, Çukurova Üniversitesi, Adana 


\section{APPENDIXES}

\section{Appendix-1:}

Independent Samples Test

\begin{tabular}{|c|c|c|c|c|c|c|c|c|c|c|}
\hline & \multicolumn{2}{|c|}{$\begin{array}{c}\text { Levene's Test for } \\
\text { Equality of Variances }\end{array}$} & \multicolumn{7}{|c|}{ t-test for Equality of Means } \\
\hline & & \multirow[t]{2}{*}{$\mathrm{F}$} & \multirow[t]{2}{*}{ Sig. } & \multirow[t]{2}{*}{$\mathrm{t}$} & \multirow[t]{2}{*}{ df } & \multirow[t]{2}{*}{$\begin{array}{l}\text { Sig. (2- } \\
\text { tailed) }\end{array}$} & \multirow[t]{2}{*}{$\begin{array}{c}\text { Mean } \\
\text { Difference }\end{array}$} & \multirow[t]{2}{*}{$\begin{array}{l}\text { Std. Error } \\
\text { Difference }\end{array}$} & \multicolumn{2}{|c|}{$\begin{array}{c}95 \% \text { Confidence Interval of } \\
\text { the Difference }\end{array}$} \\
\hline & & & & & & & & & Lower & Upper \\
\hline \multirow{2}{*}{ Adhocracy } & $\begin{array}{l}\text { Equal variances } \\
\text { assumed }\end{array}$ & 24,341 & ,000 & $-6,488$ & 477 & ,000 &,- 69751 & 10751 &,- 90876 &,- 48626 \\
\hline & $\begin{array}{l}\text { Equal variances } \\
\text { not assumed }\end{array}$ & & & $-6,412$ & 432,964 & ,000 &,- 69751 & 10878 &,- 91132 &,- 48370 \\
\hline \multirow{2}{*}{ Clan } & $\begin{array}{l}\text { Equal variances } \\
\text { assumed }\end{array}$ & 9,152 & ,003 & $-7,721$ & 476 & ,000 &,- 80123 & 10377 & $-1,00514$ &,- 59731 \\
\hline & $\begin{array}{l}\text { Equal variances } \\
\text { not assumed }\end{array}$ & & & $-7,669$ & 451,965 & ,000 &,- 80123 & ,10447 & $-1,00654$ &,- 59592 \\
\hline \multirow{2}{*}{ Hierarchy } & $\begin{array}{l}\text { Equal variances } \\
\text { assumed }\end{array}$ & 22,513 &, 000 & $-6,451$ & 476 & ,000 &,- 53762 & ,08334 &,- 70138 &,- 37386 \\
\hline & $\begin{array}{l}\text { Equal variances } \\
\text { not assumed }\end{array}$ & & & $-6,371$ & 429,842 & ,000 &,- 53762 & ,08439 &,- 70348 &,- 37175 \\
\hline \multirow{2}{*}{ Market } & $\begin{array}{l}\text { Equal variances } \\
\text { assumed }\end{array}$ & 1,162 & ,282 & $-6,531$ & 476 & ,000 &,- 62910 & ,09632 &,- 81836 &,- 43984 \\
\hline & $\begin{array}{l}\text { Equal variances } \\
\text { not assumed }\end{array}$ & & & $-6,524$ & 467,163 &, 000 &,- 62910 & ,09643 &,- 81860 &,- 43961 \\
\hline
\end{tabular}

Organizational Culture Types and Their Effects on Organizational Performance in Turkish Hospitals 
Appendix -2:

Independent Samples Test

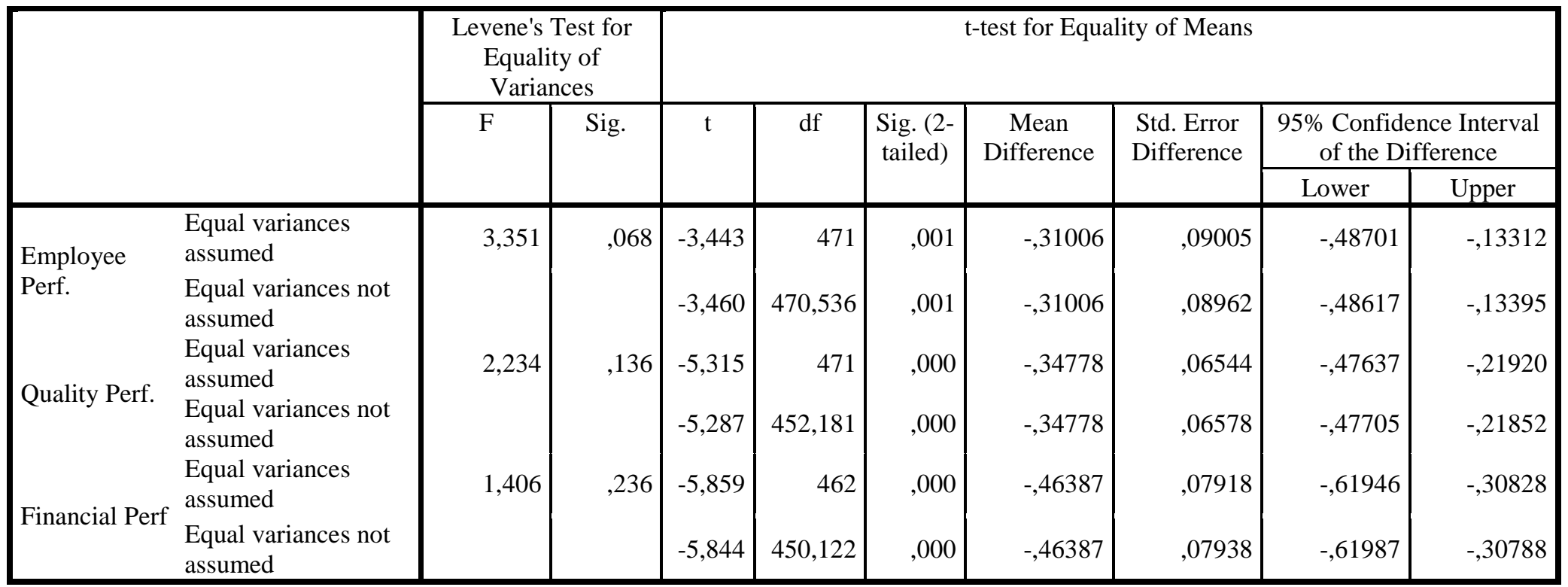

Dr. A.Zafer Acar, Pınar Acar

Page |31| Emerging Markets Journal 